The Austrian Search for Realistic Foundations

Author(s): Bryan Caplan

Source: Southern Economic Journal, Vol. 65, No. 4 (Apr., 1999), pp. 823-838

Published by: Southern Economic Association

Stable URL: http://www.jstor.org/stable/1061278

Accessed: 04/05/2009 18:47

Your use of the JSTOR archive indicates your acceptance of JSTOR's Terms and Conditions of Use, available at http://www.jstor.org/page/info/about/policies/terms.jsp. JSTOR's Terms and Conditions of Use provides, in part, that unless you have obtained prior permission, you may not download an entire issue of a journal or multiple copies of articles, and you may use content in the JSTOR archive only for your personal, non-commercial use.

Please contact the publisher regarding any further use of this work. Publisher contact information may be obtained at http://www.jstor.org/action/showPublisher?publisherCode=sea.

Each copy of any part of a JSTOR transmission must contain the same copyright notice that appears on the screen or printed page of such transmission.

JSTOR is a not-for-profit organization founded in 1995 to build trusted digital archives for scholarship. We work with the scholarly community to preserve their work and the materials they rely upon, and to build a common research platform that promotes the discovery and use of these resources. For more information about JSTOR, please contact support@jstor.org. 


\title{
The Austrian Search for Realistic Foundations
}

\author{
Bryan Caplan*
}

\begin{abstract}
Self-designated Austrian economists have two different views of modern neoclassical economics. Some, such as F. A. Hayek, take issue with certain aspects of neoclassical economics without disputing its fundamentals. Others, most notably Ludwig von Mises and Murray Rothbard, explicitly reject the foundations of neoclassical consumer and welfare theory and construct a systematic alternative. This paper analyzes the most distinctive features of the Mises-Rothbard alternative to the neoclassical paradigm; it also considers related positions defended by Israel Kirzner. I argue that their effort to rebuild economics on nonneoclassical foundations fails and that their critique of neoclassical foundations is wrong or strongly overstated.
\end{abstract}

I cannot believe that there is really anything to be ashamed of in orthodoxy. The important thing is not whether a doctrine is orthodox or the latest fashion, but whether it is true or false.

Ludwig von Mises (1980a, p. 31)

[T] here is no Austrian economics-only good economics, and bad economics.

Milton Friedman (quoted in Dolan 1976, p. 4)

\section{Introduction}

A persistent criticism of neoclassical economic theory is that it is founded on severely unrealistic assumptions. ${ }^{1}$ Friedman's (1953) reply that unrealistic assumptions are acceptable if they yield correct predictions leaves many unsatisfied. Some of this dissatisfaction stems from hostility to theory as such; critics of the realism of neoclassical assumptions rarely put forward theories of their own. One project the Austrian school of economists has pursued, however, is to rebuild economics on realistic, nonneoclassical assumptions.

Not all Austrians share this ambitious project. F. A. Hayek, the best-known member of the Austrian school, expressed unease with certain aspects of modern economics, but in large part, he viewed his work as a complement to, rather than a substitute for, the neoclassical approach. He offered a bundle of insights on information economics, the theory of the firm, monetary economics, and comparative systems (Hayek 1984) rather than new and better foundations for

* Department of Economics and Center for the Study of Public Choice, George Mason University, Fairfax, VA 22030, USA; E-mail bcaplan@gmu.edu.

I would like to thank Tyler Cowen, Peter Boettke, David Friedman, Vincent Cook, Mark Skousen, Alex Tabarrok, Karen Vaughn, seminar participants at George Mason, and two anonymous referees for helpful comments. Gisele Silva provided excellent research assistance. The standard disclaimer applies.

Received December 1997; accepted October 1998.

${ }^{1}$ For example, Boettke (1997). See also Cowen and Fink (1985), who compare the realism of Austrian and neoclassical equilibrium concepts. 
economic analysis. Perhaps to counter misunderstanding of his work, late in his career, Hayek expressed his desire to

\footnotetext{
. . avoid giving the impression that I generally reject the mathematical method in economics. I regard it as indeed the great advantage of the mathematical technique that it allows us to describe, by algebraic equations, the general character of a pattern even where we are ignorant of the numerical values determining its particular manifestation. Without this algebraic technique we could scarcely have achieved that comprehensive picture of the mutual interdependencies of the different events in the market. (Hayek 1979, p. 28)
}

Yet others within the Austrian tradition-especially Hayek's mentor Ludwig von Mises, Mises' close adherent Murray Rothbard, ${ }^{2}$ and to a lesser extent Mises' student Israel Kirzneradvance stronger claims. Mises and Rothbard together reject much of the core of neoclassical economics: for starters, utility functions, indifference analysis, continuous preferences, and nearly all of welfare economics. They then develop positive alternative foundations of economic analysis. Kirzner's project is less radical, but his disagreements with the neoclassical view of uncertainty still lead him to take issue with several basic neoclassical conclusions and offer original alternatives (Boettke 1994a).

If valid, the economics of Mises and Rothbard would require a paradigm shift for the entire discipline of economics. As Rothbard (1974) puts it, "Ludwig von Mises offers to us nothing less than the complete and developed correct paradigm of a science that has gone tragically astray over the last half-century. Mises' work presents us with the correct and radically divergent alternative to the flaws, errors and fallacies which a growing number of students are sensing in present-day economic orthodoxy" (p. 140). Embracing Kirzner's conclusions would require a similar if less dramatic transformation of the economics profession (Boettke 1994b). However, this paper argues that no paradigm shift is warranted. The objections of Mises, Rothbard, and Kirzner to standard neoclassical foundations - though often ably defended-are unsound. Nevertheless, much can be learned by taking their arguments seriously. As both Rosen (1997) and Yeager (1997) maintained in a recent debate, at least in the short-run, important imperfections may be found in the market for ideas: Imagine the intellectual analog of a speculative bubble. When critics thoughtfully argue that the market for ideas has strayed from the right path, fundamental analysis-reexamining basic premises-is the strongest answer.

This paper is divided into four sections. The next section examines and critiques the work of Mises and Rothbard on utility theory and the Mises-Rothbard and Kirznerian approaches to choice under uncertainty. The third section analyzes Rothbard's effort to reconstruct welfare economics along lines consistent with Misesian foundations; it also considers Kirzner's coordination norm. It further shows how Rothbard's revised welfare theory leads him to implausibly deny the coherence of the theory of public goods. The fourth section concludes the paper.

\footnotetext{
${ }^{2}$ Some would deny that Rothbard was in fact a faithful adherent of Mises; there is not sufficient space to address this objection in detail, but the evidence for the near-identity of their approach to economics is strong. There is no doubt that Rothbard saw himself as a follower of Mises (see, e.g., Rothbard's [1962, pp. xi-xii] Man, Economy, and State, Rothbard's essays "The Essential Von Mises" [Rothbard 1980] and "Ludwig von Mises and the Paradigm for Our Age" [Rothbard 1974], and Rothbard's [1988] biography of Mises). When Mises (1981) reviewed Man, Economy, and State, he strongly endorsed Rothbard's economics, criticizing only his legal philosophy. Mises was quite willing to criticize his former students who came to disagree with him (see, e.g., Mises [1980b] for his criticism of Gottfried Haberler [pp. 70-1] and Hayek [pp. 219-21]). While Karen Vaughn's Austrian Economics in America (1994, p. 95) is fairly unsympathetic to Rothbard, she nevertheless concedes that, "Although Rothbard absolved Mises from any responsibility for his product and considered the possibility that Mises might disagree strongly with some of Rothbard's exposition, in fact, he remained remarkably faithful to both the details of Mises' economics and to his tone of argumentation."
} 


\section{Austrian Alternatives to Neoclassical Consumer Theory}

Neoclassical consumer theory makes a number of normally uncontroversial assumptions: that agents can be indifferent between two alternatives; that agents' preferences can be represented with continuous utility functions; and that agents' ignorance and imperfect knowledge can be captured using probability theory. Mises and Rothbard reject all three of these assumptions and try to rederive economic theory without them; Kirzner focuses mostly on the neoclassical view of imperfect knowledge. Both positions are a sufficient basis for an alternative Austrian paradigm. However, Mises, Rothbard, and Kirzner reject the foundations of modern neoclassical consumer theory too quickly, and their substitutes are inadequate. ${ }^{3}$

\section{Indifference}

Perhaps the most basic assumption of consumer choice theory is that, given two choices $a$ and $b$, an agent can strictly prefer $a$ to $b(a>b)$, can strictly prefer $b$ to $a(a<b)$, or can be indifferent between $a$ and $b(a \sim b)$. While Mises and Rothbard accept the first two cases of strict preferences, they argue that the third case of perfect indifference is nonsensical because it cannot be demonstrated in action. Mises (1980a) indicated his aversion to this concept when he strongly criticized Irving Fisher's anticipation of indifference curve analysis (pp. 55-7). ${ }^{4}$ Rothbard, writing after indifference analysis had come to maturity, elaborated upon Mises's argument in greater depth.

Rothbard tightly ties his argument against indifference to Mises' analysis of the relationship between preference and action. As Mises (1966) argues, "The scale of values manifests itself only in real acting; it can be discerned only from the observation of real acting" (p. 102). Yet it is impossible for action to demonstrate indifference. Action demonstrates preference, not indifference. Rothbard (1962) puts it thusly: "The crucial fallacy is that indifference cannot be a basis for action. If a man were really indifferent between two alternatives, he could not make any choice between them, and therefore the choice could not be revealed in action" (p. 265). It is important to note that Rothbard is not saying that it is difficult to distinguish action based on strict preference from action based on indifference; rather he is saying that every action is necessarily based on strict preference. In other words, "not only are alternatives ranked ordinally on every man's value scale, but they are ranked without ties; i.e., every alternative has a different rank" (Rothbard 1962, p. 267).

The crucial assumption-shared by both Mises and Rothbard-is that all preferences can be revealed in action. But why assume this? Mises and Rothbard repeatedly disavow behaviorism; introspection yields insight in the social sciences even if it does not in the natural sciences. In his introduction to Mises' Theory and History, Rothbard writes,

One example that Mises liked to use in his class to demonstrate the difference between two fundamental ways of approaching human behavior was looking at Grand Central Station behavior during rush hour. The

"objective" or "truly scientific" behaviorist, he pointed out, would observe the empirical events: e.g., people

\footnotetext{
${ }^{3}$ Nozick (1997) presents different but complementary arguments against Mises' and Rothbard's utility theory and rejection of indifference analysis. Specifically, (i) Rothbard (1962) implicitly uses indifference analysis when he explains that the units of a good are "interchangeable from the point of view of the actor" and adds that "any concrete pound of butter was evaluated in this case perfectly equally by the individual" (pp. 18-9); (ii) subjective opportunity costs, which play a key role in the analysis of both Mises and Rothbard, are by definition preferences not revealed in action.

${ }^{4}$ For further evidence that Mises shares Rothbard's rejection of indifference analysis and neoclassical utility theory, compare Mises (1980a, pp. 51-60) to Man, Economy, and State (Rothbard 1962, pp. 260-8).
} 
rushing back and forth, aimlessly at certain predictable times of day. And that is all he would know. But the true student of human action would start from the fact that all human behavior is purposive, and he would see the purpose is to get from home to the train to work in the morning, the opposite at night, etc. It is obvious which one would discover and know more about human behavior, and therefore which one would be the genuine "scientist." (Mises 1985, p. xiv)

This critique of behaviorism in the social sciences suggests an equally cogent defense of indifference analysis. Just as there is more to my action than my behavior, there is more to my preferences than my action. I have all sorts of preferences that are not-and cannot be-revealed in action. For example, my preference for ice cream at the current instant cannot be revealed since, by the time I managed to find an ice cream vendor, the current instant would have passed. Buying ice cream 10 minutes from now only reveals a preference for ice cream then. And yet, I have introspective knowledge that I want some ice cream right now. Similarly, in a perfectly competitive market, I will never reveal my preference for products at prices other than the market price, but by introspection I can know them.

In precisely the same way, I know that I am sometimes indifferent. I am often indifferent between the colors of clothes; though I pick one color, I know that I would not mind flipping a coin to decide. The behaviorist might deny the reality of my mental states, but clearly that is not the route Mises or Rothbard would want to take. Indeed, McCulloch's (1977) formal treatment of Austrian marginal utility theory argues that behaviorism is a defect of standard consumer theory that the Austrian theory avoids:

\footnotetext{
The indifferent approach suffers from the positivistic prejudice that science can only take note of "observable" phenomena, and must never attribute human-like motives to its objects of study. The Austrian school, on the other hand, realizes that there is nothing unscientific about attributing human-like motives to human beings. (p. 270)
}

But isn't Mises' and Rothbard's rejection of indifference analysis based on the very prejudice McCulloch attributes to standard consumer theory? One can only observe that I choose a green sweater, but this does not rule out the possibility that I was actually indifferent between the green sweater and the blue sweater. As Oskar Morgenstern (1941) put it in a critique of Hicks, "[I]ntrospection might be experience as much as the observable facts of consumers' choice on the market. Some facts, as the scientist knows, are fully as empirical as others, although their direct observation is not possible ..." (p. 366). Admittedly, strict preference can sometimes be observationally distinguished from indifference; for example, in a second-price auction with a unique high bid, the high bidder will strictly prefer the object sold to the price paid for it. But this is no reason to ignore the many cases where the observed choice of A over $B$ is equally consistent with strict preference and indifference.

\section{Continuous Utility Functions Versus Discrete Value Scales}

\section{The Charge of Cardinality}

Mises (1966) repeatedly rejected anything resembling utility functions: "Values and valuations are intensive quantities and not extensive quantities. They are not susceptible to mental

\footnotetext{
${ }^{5}$ For a detailed discussion of the distinctively Austrian approach to utility theory before 1934, see High and Bloch (1989); for an early critic of neoclassical utility theory from a position similar to that of Mises and Rothbard, see Morgenstern (1941). McCulloch (1977) provides a modern, formal treatment of Austrian marginal utility theory.
} 
grasp by the application of cardinal numbers" (p. 204). He argued that other treatments of utility theory had to assume a util-a fictitious unit of utility-and that this confusion was widespread. "Even Friedrich von Wieser and Irving Fisher took it for granted that there must be something like measurement of value and that economics must be able to indicate and explain the method by which such measurement is effected" (p. 204).

Rothbard elaborates upon Mises' utility theory and critiques the use of utility functions in their modern form. According to Rothbard, the mainstream approach credulously accepts the concept of cardinal utility when only that of ordinal utility is defensible. As Rothbard (1962) insists, "Value scales of each individual are purely ordinal, and there is no way whatever of measuring the distance between the rankings; indeed, any concept of such distance is a fallacious one" (p. 222). At first, Rothbard (1962) appears to limit his criticism solely to "[t]hose writers who have vainly attempted to measure psychic gains from exchange" by their consumer's surplus (p. 223). But it soon becomes clear that Rothbard rejects the entire utility-function approach as incoherent: "The chief errors here consist in conceiving utility as a certain quantity, a definite function of an increment of the commodity. ... Utilities are not quantities, but ranks .." (p. 263). ${ }^{6}$

As if to emphasize the strength of his disagreement with the mainstream approach to utility, Rothbard (1962) goes on to dismiss the familiar intermediate micro theorem" "that in equilibrium the ratio of the marginal utilities of the various goods equals the ratio of their prices. Without entering in detail into the manner by which these writers arrive at this conclusion, we can see its absurdity clearly, since utilities are not quantities and therefore cannot be divided" (p. 262). What initially appeared to be a slight difference in nomenclature yields disagreement about basic issues.

While the exposition of utility theory in undergraduate textbooks may sometimes be open to Rothbard's critique of cardinality, neoclassical utility theory is no less ordinal than his own theory (see, e.g., Varian 1992, pp. 95-7). Let a neoclassical theorist say "bundle one offers utility of 8 , while bundle two offers utility of 7," and Rothbard concludes that he believes in cardinal utility. But the language here is technical; to parse it, you must return to the underlying definitions. The meaning of "bundle one offers utility of 8 , while bundle two offers utility of 7 " is nothing more or less than "bundle one is preferred to bundle two." A utility function is just a short-hand summary about an agent's ordinal preferences, not a claim about utils. This is why it is often said that the utility function is uniquely defined up to a monotonic transformation. If one utility function represents an agent's preferences, then those preferences can also be represented by any other function that leaves the order unchanged.

\section{The Objection to Continuity}

Mises and Rothbard have a second related objection to standard neoclassical utility theory: the assumption of continuity. As Mises (1980a) argues, "[T]he peculiarly mathematical con-

\footnotetext{
${ }^{6}$ It should, however, be pointed out that one of Rothbard's earlier essays evinced a more sophisticated understanding of modern utility theory. In particular, he noted the differences between " 'measurable up to a multiplicative constant' (cardinal); 'measurable up to a monotonic transform' (ordinal); 'measurable up to a linear transform' (the new quasimeasurement, of which the Neumann-Morgenstern proposed utility index is an example)..." But Rothbard (1956) still ultimately objected that all were confused, for "subjective states, being intensive rather than objectively extensive, cannot be measured and subjected to arithmetic operations. And utility refers to intensive states" (p. 241).

${ }^{7}$ Nicholson explains utility theory using both marginal rates of substitution and marginal utility, although he gives more emphasis to the former (1989, pp. 75-129).
} 
ception of infinitesimal quantities is inapplicable to economic problems. The utility afforded by a given amount of commodities, is either great enough for valuation, or so small that it remains imperceptible to the valuer and therefore cannot affect his judgment" (p. 57). Rothbard (1962) makes the same point: "[H]uman beings act on the basis of things that are relevant to their action. The human being cannot see the infinitely small step; it therefore has no meaning to him and no relevance to his action" (p. 264).

The implication is significant because a function must be continuous to be differentiable. Hence, Rothbard infers, most of mathematical economics rests upon a fundamental mistake and must be discarded. One might reply that the unrealism of continuity is only minor; Rothbard (1962) considers this possibility and rejects it: "Most writers on economics consider this assumption a harmless, but potentially very useful, fiction, and point to its great success in the field of physics. ... The crucial difference is that physics deals with inanimate objects that move but do not act" (p. 264). Real choice is always discrete choice; ignoring this fact can only lead economists into error.

Rejecting continuity, however, requires Rothbard to reject more than just utility curves. If continuity assumptions cannot be used because "human beings cannot see the infinitely small step," then it will also be impossible for humans to see not only infinitely small amounts of a good but infinitely small steps of a given monetary unit. But with a discrete good and a discrete monetary unit, it is unlikely that supply and demand will ever be equal; no equilibrium price need exist. ${ }^{8}$ Excess demand may be -2 units when the price is $\$ 1.01$ and +1 unit when the price is $\$ 1.00$. Thus, the argument against calculus based upon the rejection of continuity also argues against the use of simple algebraic constructs, like intersecting supply and demand lines, that fill Rothbard's works.

Rothbard runs into a contradiction. If the assumption of continuity is not a harmless fiction, then it is incumbent upon him to remove all of the supply and demand intersections in his works and to state that supply equals demand only under extremely rare conditions. ${ }^{9}$ Alternately, Rothbard could concede that assuming continuity rarely alters substantive results and accept both supply and demand intersections and the use of calculus as methodologically acceptable in economics.

\section{The Income and Substitution Effects}

Though Rothbard rejects neoclassical utility theory, he makes ad hoc concessions to it elsewhere in his writings. Using his value scale approach, Rothbard (1962) claims to derive the laws of demand and supply as exceptionless theorems. When he says "demand must either increase or remain the same as the price decreases" and "supply must always remain unchanged or increase with an increase in price," he literally means "must" (pp. 106-7; emphasis mine). But in his later discussion of labor and land, Rothbard concedes the theoretical possibility of backward bending supply curves (pp. 515-6). Furthermore, in his treatment of the economics

\footnotetext{
${ }^{8}$ As an anonymous referee pointed out, if the goods are discrete but the monetary unit is continuous, then there will typically be multiple equilibria, a range of prices that clear the market. This still permits what the Austrians call a theory of price formation (as opposed to price determination) that sets upper and lower bounds on the possible market price.

${ }^{9}$ Rothbard (1962) admits that his arguments against mathematics in economics do not hold when "[w]e are not dealing with human decisions ... but with the necessary technological conditions of the world as given to human factors" (p. 460). But this exception does not help salvage continuous demand curves or the existence of market-clearing prices, which do involve human decisions and not technology alone.
} 
of taxation, Rothbard admits the theoretical possibility that greater taxation of labor income could induce an increase in labor supplied, going so far as to mention a substitution and an income effect, which his initial treatment of utility theory and demand fails to mention and indeed directly contradicts (p. 797). What is interesting is that Rothbard is unable to derive the substitution and income effects from his value scale approach. While he dismisses the neoclassical approach to utility theory, Rothbard deems it sufficiently fruitful that he borrows its implications on an ad hoc basis. ${ }^{10}$ In short, this is a bona fide case where neoclassical economists did not merely tediously formalize the obvious but actually gained new and intuitive insight by consistently applying their standard approach.

\section{Uncertainty and Probability}

Economic agents have to make decisions in a world of uncertainty; but what exactly does uncertain mean?"1 In neoclassical analysis, it simply means that there exists a known probability distribution (objective or subjective) with more than one possible outcome (Varian 1992, pp. 172-97). Choice in the real world of uncertainty is no different from playing a game with known rules and multiple possible outcomes. Mises and Rothbard, however, insist that most economic uncertainty simply defies quantification; there is usually no known probability distribution for agents to use. ${ }^{12}$

Mises (1966) distinguishes between class probability and case probability: ${ }^{13}$

\footnotetext{
Class probability means: We know or assume to know, with regard to the problem concerned, everything about the behavior of a whole class of events or phenomena; but about the actual singular events or phenomena we know nothing but that they are elements in this class. (p. 107)

Case probability means: We know, with regard to a particular event, some of the factors which determine its outcome; but there are other determining factors about which we know nothing. (p. 110)
}

Mises insists that only class probability can be meaningfully quantified, whereas the quantification of case probability is at best metaphorical. One can make meaningful quantitative statements about the probability that someone will win a lottery since we can find out the behavior of the whole class of lottery tickets. But it is meaningless to quantify the probability that Al Gore will win the 2000 presidential election. The latter is, in Mises' (1966) words, "an individual, unique, and nonrepeatable case" (p. 111). Since there is only one such election, it

\footnotetext{
${ }^{10}$ McCulloch (1977) provides a more sophisticated and formal presentation of Austrian utility theory but still does not derive the income and substitution effects, although he also does not show that such a derivation is impossible.

${ }^{11}$ See, for example, Weatherford (1982) for a survey of the main interpretations of probability theory; for a recent defense of Bayesian reasoning in the sciences and in general, see Howson and Urbach (1989).

${ }^{12}$ Rothbard (1979) is particularly emphatic about how rarely uncertainty can be legitimately quantified: "In the real world of human action, virtually all historical events are unique and heterogeneous.... Since each event is unique and nonreproducible, it is impermissible to apply objective probability theory; expectations and forecasting become a matter of subjective estimates of future events, estimates that cannot be reduced to an objective or 'scientific' formula. It is no accident that social scientists arguing for the use of the objective probability calculus almost invariably cite the case of the lottery; for a lottery is one of the few human situations where the outcomes are indeed homogeneous and reproducible..." (pp. 93-4). Note that, as the rest of the section shows, Rothbard, like Mises, claims that only objective probabilities (class probabilities) admit of quantification.

${ }^{13}$ Mises' class probability appears to be the same as objective probability, but case probability does not readily translate to subjective probability. In particular, subjective probabilities can be quantified, but Mises' case probabilities cannot be (see Langlois [1994] for an attempt to translate Mises' terminology into more familiar categories). Note further that, while Ludwig von Mises' view resembles the relative frequency theory for which his brother Richard von Mises (1957) is known, there is no reason to think that their views were identical.
} 
is impossible to observe multiple members of the class and calculate the frequency with which Gore wins.

Rothbard firmly embraces Mises' distinction and notes its close relationship to Frank Knight's bifurcation of risk and uncertainty (Knight 1985). One can insure against risk; the class probability of fire hazards, accidental death, and so on can be readily quantified. But it is not possible to insure against the true uncertainty of unique events because these are instances of unquantifiable case probability. While Mises and Rothbard acknowledge that quantifiable class probability plays some role in economic life, they insist that economic actors usually have nothing better than case probability to work with. Entrepreneurs in particular have to make choices without a known probability distribution; as Rothbard (1962) argues, "Estimates of future costs, demands, etc., on the part of entrepreneurs are all unique cases of uncertainty, where methods of specific understanding and individual judgment of the situation must apply, rather than objectively measurable or insurable 'risk' "' (p. 500).

Mises (1966) is convinced that his analyis of probability is "the only logically satisfactory one" (p. 109). He overlooks some serious difficulties. ${ }^{14}$ Most fundamentally, every event is unique; if quantitative probability does not apply to unique events, then quantitative probability never applies to actual, specific situations (Weatherford 1982, pp. 161-7, 227-33). Even in games of chance, all draws and throws are "individual, unique, and nonrepeatable." Dice are always rolled at a particular time and place, in casinos of varying honesty, so we never "know nothing but that they are elements" of the class of dice. Additional information inevitably accompanies every real case. Unless the probability of some unique events can be quantified, Mises seems forced to deny that probability can ever be quantified.

One might think that Mises' and Rothbard's strictures against quantifiable probabilities would be unique to them. ${ }^{15}$ Yet a fairly large fraction of recent Austrian research (including Thomsen 1992; Vaughn 1992; O’Driscoll and Rizzo 1996; Kirzner 1997) attaches great significance to this issue without necessarily adhering exactly to the Mises-Rothbard position. Israel Kirzner's (1997) recent and comprehensive article contrasts the stochastic ignorance of neoclassical models with the "sheer" ignorance of the Austrian approach:

For the Austrian approach imperfect information is seen as involving an element which cannot be fitted at all into neoclassical models, that of 'sheer' (i.e., unknown) ignorance.... [S]heer ignorance differs from imperfect information in that the discovery which reduces sheer ignorance is necessarily accompanied by the element of surprise-one had not hitherto realized one's ignorance. (p. 62)

Kirzner gives considerably wider scope for known probability distributions than Mises or Rothbard but still defends some role for unquantifiable uncertainty. ${ }^{16}$ "In the economics of

${ }^{14}$ For a summary of the standard objections to relative frequency views of probability, see Weatherford (1982, pp. 199217).

${ }^{15}$ It should, however, be pointed out that even some mathematically inclined probability theorists agree that quantitative probabilities are sometimes inapplicable. For example, Burks (1977) states: "But it is a distortion to use real numbers for all applications of the concept of probability... . No scientist would assign a precise number to such a speculation as the theory of the continuous creation of matter on the basis of his present information. Exactly what probability do you attach to the statement 'There was once a battle as Birdun'? Clearly, many real-life situations of uncertainty are not quantitative in nature" (p. 187).

${ }^{16}$ One referee argues that Kirznerian sheer ignorance is unquantified rather than unquantifiable uncertainty: "Sheer ignorance doesn't mean that I can't meaningfully assign a quantitative probability to event $x$; it means that I have disregarded the possibility of event x.... It didn't make [my] list of events to which probabilities were assigned." Still, Kirzner seems to hold that it is virtually impossible for anyone to ever have a complete list of events to which probabilities may be assigned. At least empirically, if not logically, unquantifiable uncertainty is always with us, which precludes, for example, the calculation of the expected value of overlooked profit opportunities. It is also worth mentioning that the distinction between failing to assign an event a probability and assigning it a zero probability is tenuous; what is the difference between failing to pay me and paying me zero dollars? 
search literature, therefore, search is correctly treated as any other deliberate process of production. But it is in the nature of an overlooked profit opportunity that it has been utterly overlooked, i.e., that one is not aware at all that one has missed the grasping of any profit" (p. 71). Thomsen (1992) is particularly ecumenical, but shares Kirzner's concern that there is sometimes more to uncertainty than known probability distributions:

[T] he fertility of approaches such as that of the economics of information and of search theory may lead some economists into believing that all problems of knowledge in an economy are being studied. It will be argued that these approaches, because they treat knowledge as just another scarce good, do not fully encompass the knowledge problem faced in reality and in fact underestimate it. If they were to mislead economists into overlooking a more radical type of ignorance, they would have obstructed a fuller comprehension of prices and markets. (p. 5)

But why should economists believe that any more radical type of ignorance exists? For Kirzner (1997), sheer ignorance explains why discoverers experience surprise: "What distinguishes discovery . . . from successful search ... is that the former (unlike the latter) involves that surprise which accompanies the realization that one had overlooked something in fact readily available. ('It was right under my very nose!')" (p. 72). Yet there is a simpler explanation consistent with standard probability theory: Improbable outcomes are inherently surprising. When you win a massive jackpot at a slot machine, you are likely to feel surprised precisely because the odds were loudly advertised as "one-in-a-million." 17

Kirzner (1997) also insists that sheer ignorance is necessary to explain entrepreneurship: "In standard neoclassical equilibrium theory there is, by its very character, no role for the entrepreneur. In equilibrium there is no scope for pure profit: there is simply nothing for the entrepreneur to do" (p. 69). To the contrary, entrepreneurship can be seen as equilibrium search conducted by people with a comparative advantage in spotting investment opportunities. Expectationally, they earn no pure profits but rather receive a standard return on their search abilities. What look like enormous entrepreneurial profits are due to exceptional ex ante search abilities and/or luck. There is no need to make exceptions to the universal applicability of probability theory in order to explain Henry Ford or Bill Gates.

Kirzner (1979) himself concedes the possibility of this route: "[O]ne might insist that an agent not blessed with the alertness needed to notice resources available at hand, simply lacks, through no 'fault' of his own, another 'resource' (i.e., 'alertness') necessary to take advantage of the resources with which he has been blessed. We cannot set down such a use of terms as wrong" (p. 130). But if there is a standard neoclassical way to view alertness, why should Kirzner's alternative be accepted? The quote continues:

\footnotetext{
We simply point out that while decisions can in principle be made by a person lacking any needed resources, including "knowledge," to acquire that resource he lacks, we cannot conceive of one who lacks alertness making a decision to acquire it. This is so because, among other reasons, before a decision to acquire anything can be considered, one must already assume the alertness necessary for the perception that such an acquisition is needed and possible at all. (pp. 130-1)
}

Again, this argument is overstated. True, it would be impossible for a completely unaware person to decide to acquire some alertness. But this would not preclude a person with some

\footnotetext{
${ }^{17}$ If one literally assigned a probability of zero (or failed to assign a positive probability) to an event that actually happens, one would be yet more surprised. But, continuity aside, why would a rational agent assign a zero probability to a conceivable event? Moreover, if there is a small probability that one is delusional, the perception of a zeroprobability event would rationally provoke one to doubt one's own perception rather than believe that the impossible has occurred.
} 
degree of alertness deciding to try to acquire more. In short, the initial endowment of human capital of almost all people includes some degree of alertness, which is combined with other resources to produce greater alertness, and so on.

Neoclassical theory treats all uncertainty as quantifiable. Mises, Rothbard, and more recent Austrian writers argue that this is a prime example of the unrealism and implausibility of neoclassical assumptions. But the neoclassical view looks commonsensical when compared to the Austrian view that some uncertainty simply defies quantification. As Weatherford (1982) puts it in a slightly different context, "[C]ould anyone convince a working astronomer that ... there might be no probability that a star is a red giant? What would it mean to say that there is no probability that a star is a red giant when we know that many are red giants?" (p. 204). Action absent any knowledge of the probabilities of different events is hard to conceive. If you could either have $\$ 10$ with certainty or $\$ 100$ with an unquantifiable probability, it is unclear how you would decide. Mises, Rothbard, and Kirzner all require actors to weigh incommensurables, to somehow trade off known probabilities against the unquantifiable. As de Finetti (1980) forcefully puts it, "The [Bayesian] notion of probability which we have described is without doubt the closest to that of 'the man in the street'; better yet, it is that which he applies every day in practical judgments. Why should science repudiate it?"' ${ }^{18}$ (p. 71).

\section{Reconstructing Welfare Economics}

While Rothbard and Mises had similar objections to neoclassical utility theory, Mises had only a preliminary critique of modern welfare economics. Rothbard goes one step beyond Mises by reconstructing welfare economics along what he sees as Austrian lines. Rothbard's main conclusions are simple and austere: Every market transaction increases the utility of all participants, while every act of government intervention increases the utility of some people and reduces the utility of others. Rothbard draws the further implication that the theory of public goods fails to show that government action can be welfare enhancing. ${ }^{19}$ Kirzner's alternative welfare economics offers a more subtle analysis but, as shall be seen, it depends critically upon accepting the existence of Kirznerian radical ignorance.

\footnotetext{
${ }^{18}$ While Langlois (1986) argues for the existence of radical uncertainty, he presents the contrary position very effectively: "[I]t is always possible to redefine the set of events so that what was an unanticipated event falls into an anticipated category. 'Give me an example of an unanticipated event,' my interlocutors demand. How about the Trojan Horse? 'That's just a military "trick"; tricks are a concept the Trojans were familiar with, and they could have anticipated that kind of strategy and assigned a probability to it.' Well, consider the many possibilities attendant on the introduction of a technical innovation. Surely some probabilities can't be anticipated? 'Just divide the world into two events: "innovation succeeds" and "innovation fails." These are well-defined, collectively exhaustive, and mutually exclusive events over which we can define probabilities", (pp. 181-2).

${ }^{19}$ Buchanan's (1969) defense of what he calls the London-Austrian view of opportunity costs presents a thesis not too different from that of Mises and Rothbard: "In order to estimate the size of the [optimal Pigovian] tax, however, some objective measurement must be placed on these external costs. But the analyst has no benchmark from which plausible estimates can be made. Since the persons who bear these 'costs'- those who are externally affected-do not participate in the choice that generates the 'costs,' there is simply no means of determining, even indirectly, the value that they place on the utility loss that might be avoided" (p. 72). But in contrast to Mises and especially Rothbard, Buchanan's skepticism about welfare economics does not greatly incline him to reject standard Pigovian-type policy prescriptions in his other writings (DiLorenzo 1990). On the London-Austrian view of costs, see also Buchanan and Thirlby (1981), including Coase (1981).
} 


\section{Demonstrated Preference, Social Utility, and the Coordination Norm}

“Action," explains Mises (1966), "is an attempt to substitute a more satisfactory state of affairs for a less satisfactory one. We call such a willfully induced alteration an exchange. A less desirable condition is bartered for a more desirable" (p. 97). At least ex ante, action makes an isolated individual better off in his own eyes. If two people make a voluntary exchange, it then follows that both are better off in their own eyes. Rothbard (1962) draws the further implication that coercion "signifies per se that the individual or individuals being coerced would not have voluntarily done what they are now being forced to do by the intervener... The man being coerced, therefore, always loses in utility as a result of the intervention ..." (p. 769).

Mises and Rothbard so far appear to be in total agreement with neoclassical micro theory. When Rothbard (1956, pp. 244-55) unreservedly accepts Pareto's unanimity criterion for welfare analysis, it looks as if he will reinvent the wheel. But then Rothbard (1962) quickly arrives at an exceptionless welfare theorem normally believed to depend upon a large set of assumptions: "If we may use the term 'society' to depict the pattern, the array, of all individual exchanges, then we may say that the free market maximizes social utility, since everyone gains in utility from his free action" (p. 768). This claim might be rephrased to say that each voluntary exchange benefits all participants and the free market permits the implementation of all desired voluntary exchanges.

While this conclusion appears to be a simplistic non sequitur, it follows immediately from his unusual utility theory. For Mises or Rothbard, it is simply confused to posit latent preferences; if two individuals fail to make an exchange, then this ipso facto demonstrates that at that moment at least one of them would not have benefited from the exchange. Similarly, Rothbard (1977) rejects the argument that an externality, such as the envy of a third party, vitiates the principle that voluntary exchange increases social utility:

\footnotetext{
We cannot, however, deal with hypothetical utilities divorced from concrete action. We may, as praxeologists, deal only with utilities that we can deduce from the concrete behavior of human beings. A person's 'envy,' unembodied in action, becomes pure moonshine from a praxeological point of view. . . How he feels about the exchanges made by others cannot be demonstrated unless he commits an invasive act. Even if he publishes a pamphlet denouncing these exchanges, we have no ironclad proof that this is not a joke or a deliberate lie. (p. 18)
}

Indeed, Rothbard could have taken this principle further. When two people sign a contract, do they actually demonstrate their preference for the terms of the contract? Perhaps they merely demonstrate their preference for writing their name on the piece of paper in front of them. There is no ironclad proof that putting one's name on a piece of paper is not a joke or an effort to improve one's penmanship.

Rothbard's view is stronger than the truism that, taking transactions costs into account, every state of affairs is necessarily Pareto optimal (Demsetz 1988, pp. 63-4). While he would agree with this truism, Rothbard also holds-as orthodox neoclassicals would not-that every voluntary exchange is necessarily a Pareto improvement since external effects arguments constitute illegitimate appeals to latent preferences. It is important to note, however, that Rothbard does not claim that government intervention reduces social utility. ${ }^{20}$ Since the victim loses and the intervener gains from the application of coercion, it would be impossible to assert this

\footnotetext{
${ }^{20}$ Joseph Salerno (1993, p. 131) claims to produce an argument that intervention actually reduces social utility, although he notes that this conclusion is stronger than Rothbard's.
} 
without making a verboten interpersonal welfare comparison. Rothbard could only claim the welfare effect of government intervention upon social utility is indeterminate. This is an important point because it shows that Rothbard's welfare economics provides a much weaker defense of laissez-faire than usually assumed. In particular, Rothbard's own theory strips him of the ability to call any act of government inefficient. By denying others the ability to endorse state action in the name of efficiency, Rothbard also implicitly denies his own ability to reject state action in the name of efficiency. His welfare criterion justifies agnosticism about-not denial of-the benefits of state action (Prychitko 1993).

Rothbard's refusal to acknowledge unobserved preferences would have to impress even B. F. Skinner. What possible reason could we have to believe that utility is "moonshine" unless expressed in concrete actions? At every moment, by introspection we are aware of unrevealed preferences. Figuring out the mental states of other people is more difficult, but that hardly shows that their mental states do not exist. One could reverse Rothbard's objection and claim that, since there is no ironclad proof that third parties do not object to other people's voluntary exchanges, it is impossible to say whether they increase social utility. Thus, Rothbard's welfare economics terminates in agnosticism about not only the effects of intervention but the benefits of voluntary exchange.

Israel Kirzner's coordination norm is the main Austrian competitor to Rothbard's approach (Kirzner 1973, 1988, 1997). By Kirzner's (1988) admission, coordination at first seems to differ little from Pareto optimality: "Any sub-optimal situation (in the Paretian sense) clearly corresponds to the failure of a pair of potential market participants to trade with one another on feasible, mutually attractive terms-in other words, it corresponds to a failure to achieve coordination" (p. 82). But he disavows the truism (which he terms Panglossian paralysis) that, taking transactions costs into account, the world is always Pareto optimal (and hence always perfectly coordinated). How does Kirzner avoid Panglossian paralysis? Kirzner (1988) appeals again to "sheer ignorance," which gives rise to "[g]enuine error . . where a decision-maker's ignorance is not attributable to the costs of search, or of learning or communication" (p. 85). Not only does the existence of genuine error mean that Pareto improvements are possible; it also means that institutions can be evaluated according to their propensity to encourage entrepreneurs to discover genuine errors.

The core difference between Kirzner and Rothbard amounts to this: Rothbard actually embraces what Kirzner calls Panglossian paralysis in the ex ante sense. For Kirzner (1988), in contrast, recognizing the role of sheer ignorance "introduces a degree of 'looseness" " (p. 86) that leaves room for further welfare improvements. If one denies the coherence of sheer ignorance, Kirzner's position becomes the truism that the world is Pareto optimal taking transactions costs into account. ${ }^{21}$

Many, if not most, economists would agree with Rothbard that efficiency alone is an inadequate normative criterion (Rothbard 1997a, b). But Rothbard (1979) also harshly criticizes the coherence of the modern neoclassical approach to welfare economics, which labels reallocations efficient so long as they are "potentially Pareto superior." ${ }^{22}$ While justice and efficiency

\footnotetext{
${ }^{21}$ It is unclear whether Kirzner would endorse Rothbard's stronger view that every voluntary exchange is necessarily a Pareto improvement. In spite of his praise for Rothbard's work on utility and welfare economics (Kirzner 1988), Kirzner neither affirmed nor disavowed Rothbard's view that only preferences demonstrated in action have economic significance.

${ }^{22}$ See Posner (1998, pp. 12-7) for a discussion of neoclassical efficiency concepts; for an Austrian critique of the use of wealth maximization as a normative criterion, see also Rizzo (1979).
} 
are not the same, this criterion of efficiency has many advantages over Rothbard's approach. In particular, it actually allows one to make efficiency judgments about the real world-to judge, for example, that Communism was inefficient or rent control is inefficient or piracy was inefficient. Determining the normative import of efficiency can then, as Rothbard suggests, be delegated to ethicists.

\section{Public Goods}

At times, Mises seems to have a standard neoclassical analysis of the public goods problem, albeit one that puts the blame on poorly defined property rights rather than the free market as such:

[W] here a considerable part of the costs incurred are external costs from the point of view of the acting individuals or firms, the economic calculation established by them is manifestly defective and their results deceptive. But this is not the outcome of alleged deficiencies inherent in the system of private ownership of the means of production. It is on the contrary a consequence of loopholes left in this system. It could be removed by a reform of the laws concerning liability for damages inflicted and by rescinding the institutional barriers preventing the full operation of private ownership. (Mises 1966, pp. 657-8)

But Mises' analysis of positive externalities (and therefore public goods generally) quickly turns Rothbardian. Mises observes that government-owned or subsidized projects, including those with positive spillovers, use scarce resources. Few, if any, economists would disagree with this point. But then Mises makes the more controversial inference that, because government support of public goods reduces the supply of private goods, this intervention necessarily reduces consumer welfare. As Mises (1966) argues,

For every unprofitable project that is realized by the aid of the government there is a corresponding project the realization of which is neglected merely on account of the government's intervention. Yet this nonrealized project would have been profitable, i.e., it would have employed the scarce means of production in accordance with the most urgent needs of the consumers. From the point of view of the consumers the employment of these means of production for the realization of an unprofitable project is wasteful. It deprives them of the satisfactions they prefer to those which the government-sponsored project can furnish them. (p. 659)

Thus, while Mises' analysis initially sounds neoclassical, his discussion of positive externalities appears to make the strong claim that the free market ipso facto serves the most urgent needs of the consumers.

Rothbard's (1962) critique of neoclassical public goods theory is quite similar to Mises', but Rothbard derives his objections from his novel utility theory, making the critique clearer and more general:

As for the recipients, they are being forced by the State to pay for benefits that they otherwise would not have purchased. How can we say that they "benefit"? A standard reply is that the recipients "could not" have obtained the benefit even if they wanted to buy it voluntarily. The first problem here is by what mysterious process the critics know that the recipients would have liked to purchase the "benefit." Our only way of knowing the content of preference scales is to see them revealed in concrete choices. Since the choice concretely was not to buy the benefit, there is no justification for outsiders to assert that B's preference scale was "really" different from what was revealed in his actions. (p. 890)

While the argument follows from Rothbard's utility theory, that utility theory, as previous sections argued, is mistaken. ${ }^{23}$ To reiterate, contra Rothbard, preferences can exist without being

\footnotetext{
${ }^{23}$ A recent Austrian work on externalities concurs that Rothbard's approach to externalities is defective but arrives at an almost equally radical rejection of the neoclassical theory: "The Pigovian approach to both defining and resolving externality problems is completely undermined when the foundation provided by a perfectly competitive general equilibrium is withdrawn. Outside of this framework the orthodox tax and subsidy approach to such issues is vacuous" (Cordato 1992, p. 111). See also the critique of Cordato by Prychitko (1993).
} 
acted upon. Economists applying public goods theory have all too often failed to consider the possibility that consumers' valuation of the alleged public good is less than its cost of production. But just because some people misuse an economic theory does not invalidate it. Rothbard was also correct to wonder why actors refrain from bargaining to solve the public goods problem; the vast transactions cost literature sparked by Ronald Coase (1960) provides most of the answer.

When Rothbard wrote his critique of public goods theory in 1962, most economists saw public goods problems only in markets. Subsequent scholarship, however, has emphasized that any institution, including the government, may suffer from this imperfection. Mancur Olson's The Logic of Collective Action (1971) showed how the public goods problem can make government work poorly; a vast public choice literature builds on this premise (Mueller 1997). Indeed, Rothbard's (1977) own analysis of the ex post utility of democratic action implicitly uses the same idea (pp. 18-23). Rothbard's a priori rejection of the concept of public goods was simply the wrong route to take; it would have been more productive to point out the public goods problems of government along with the surprising ability of free markets to supply voluntary solutions to genuine public goods problems (Cowen 1992).

\section{Conclusion}

The Austrian challenge to the realism of neoclassical assumptions actually helps make those assumptions more plausible. Setting aside arguments about predictive ability (Friedman 1953), neoclassical economic theory often looks realistic next to various Austrian challenges. Standard consumer theory affirms that preferences exist regardless of whether they are revealed in action and that people are sometimes indifferent when they act. Rebuilding consumer theory on the contrary view makes the Mises-Rothbard approach less, not more, realistic. Neoclassical theory treats all ignorance as quantifiable in terms of probability theory. Even if this sounds implausible at first, it makes a lot of sense compared to the various Austrian versions of literally unquantifiable uncertainty. In particular, the more carefully Kirzner spells out the implications of radical ignorance the stranger and less realistic they grow. Consider, for example, Kirzner's (1973) claim that "no monopoly over entrepreneurship is imaginable (since no resources are required for pure entrepreneurship) ..." (p. 103). Yet it is difficult to see how anything can be accomplished with zero resources. Isn't there an opportunity cost of mental effort?

The same holds for the Austrian alternatives to neoclassical welfare economics. Common sense balks when Rothbard rules out any discussion of public goods on the grounds that it impermissibly discusses preferences not revealed in action. It is similarly implausible for Kirzner to appeal to radical ignorance to avoid Panglossian paralysis. Taking transactions costs into account, Kirzner (1988) tells us the world is still not Pareto optimal because there is "ignorance ... not attributable to the costs of search, or of learning or communication" (p. 85). While applying the standard neoclassical Kaldor-Hicks criterion in practice is often difficult, the very coherence of Kirzner's key concept is doubtful. ${ }^{24}$

Mises, Rothbard, and Kirzner make an impressive attempt to produce a sound alternative

\footnotetext{
${ }^{24}$ If one accepts my critiques of Mises and Rothbard but not Kirzner, it suggests that Kirzner can be most profitably viewed as a synthesis of Hayek and neoclassicism rather than a synthesis of Hayek and Mises (see, e.g., Kirzner 1997, pp. 67-74).
} 
foundation for economics; yet in the final analysis, their proffered foundations are incorrect. Other Austrians, such as O'Driscoll and Rizzo (1996), make no claim to have a new, welldeveloped alternative to neoclassical economics, although they hope to ultimately develop one. ${ }^{25}$ Exploration of uncharted alternatives may be a useful form of intellectual diversification, but it is a shaky basis for a paradigm shift. The reasonable intellectual course for Austrian economists to take is to make specific, substantive contributions to economics as Hayek did, and as both Rosen (1997) and Yeager (1997) recommend, and wait to see if the sum of these specific contributions adds up to a novel alternative to the neoclassical approach.

\section{References}

Boettke, Peter. 1994a. Introduction. In The Elgar companion to Austrian economics, edited by P. Boettke. Cheltenham, UK: Edward Elgar, pp. 1-6.

Boettke, Peter. 1994b. Alternative paths forward for Austrian economics. In The Elgar companion to Austrian economics, edited by P. Boettke. Cheltenham, UK: Edward Elgar, pp. 601-15.

Boettke, Peter. 1997. Where did economics go wrong? Modern economics as a flight from reality. Critical Review 11: 11-64.

Buchanan, James. 1969. Cost and choice. Chicago: University of Chicago Press.

Buchanan, James, and G. F. Thirlby, eds. 1981. L.S.E. essays on cost. New York: New York University Press.

Burks, Arthur. 1977. Chance, cause, reason. Chicago: University of Chicago Press.

$\rightarrow$ Coase, Ronald. 1960. The problem of social cost. Journal of Law and Economics 3:1-44.

Coase, Ronald. 1981. Business organization and the accountant. In L.S.E. essays on cost, edited by J. Buchanan and G. F. Thirlby. New York: New York University Press, pp. 97-132.

Cordato, Roy. 1992. Welfare economics and externalities in an open ended universe: A modern Austrian perspective. Boston: Kluwer Academic Publishers.

Cowen, Tyler. 1992. Public goods and market failures: A critical examination. New York: Transaction Publishers.

Cowen, Tyler, and Richard Fink. 1985. Inconsistent equilibrium constructs: The evenly rotating economy of Mises and Rothbard. American Economic Review 75:866-9.

Demsetz, Harold. 1988. The cost of transacting. In Ownership, control, and the firm. Cambridge, MA: Basil Blackwell, pp. 63-81.

DiLorenzo, Thomas. 1990. The subjectivist roots of James Buchanan's economics. Review of Austrian Economics 4 : 180-95.

Dolan, Edwin. 1976. The foundations of modern Austrian economics. Kansas City: Sheed and Ward.

Finetti, Bruno de. 1980. Foresight: Its logical laws, its subjective sources. In Studies in subjective probability, edited by H. Kyburg and H. Smokler. Huntington, NY: Robert E. Krieger Publishing, pp. 51-118.

Friedman, Milton. 1953. The methodology of positive economics. In Essays in positive economics. Chicago: University of Chicago Press, pp. 3-43.

Hayek, Friedrich A. 1979. The pretense of knowledge. In Unemployment and monetary policy. Washington, DC: Cato Institute, pp. 21-36.

Hayek, Friedrich A. 1984. The essence of Hayek. Stanford, CA: Hoover Institution Press.

High, Jack, and Howard Bloch. 1989. On the history of ordinal utility theory: 1900-1932. History of Political Economy 21:351-65.

Howson, Colin, and Peter Urbach. 1989. Scientific reasoning: The Bayesian approach. LaSalle, IL: Open Court.

Kirzner, Israel. 1973. Competition and entrepreneurship. Chicago: University of Chicago Press.

Kirzner, Israel. 1979. Economics and error. In Perception, opportunity, and profit. Chicago: University of Chicago Press, pp. $120-36$.

Kirzner, Israel. 1988. Welfare economics: A modern Austrian perspective. In Man, economy, and liberty: Essays in honors of Murray N. Rothbard, edited by W. Block and L. Rockwell. Auburn, AL: Ludwig von Mises Institute, pp. $77-88$.

Kirzner, Israel. 1997. Entrepreneurial discovery and the competitive market process: An Austrian approach. Journal of Economic Literature 35:60-85.

25 "If, however, we were to characterize the subjectivist literature generally, we would have to admit that it has been relatively long on methodological prescriptions and short on applications. It is time to do the difficult work of applying subjectivist ideas to actual problems" (O’Driscoll and Rizzo 1996, p. 231). 
Knight, Frank. 1985. Risk, uncertainty and profit. Chicago: University of Chicago Press.

Langlois, Richard. 1986. Coherence and flexibility: Social institutions in a world of radical uncertainty. In Subjectivism, intelligibility, and economic understanding, edited by I. Kirzner. New York: New York University Press, pp. 171-91.

Langlois, Richard. 1994. Risk and uncertainty. In The Elgar companion to Austrian economics, edited by P. Boettke. Cheltenham, UK: Edward Elgar, pp. 118-22.

McCulloch, J. Huston. 1977. The Austrian theory of the marginal use and ordinal marginal utility. Zeitschrift für nationalökonomie 37:249-80.

Mises, Ludwig von. 1966. Human action. Chicago: Contemporary Books.

Mises, Ludwig von. 1980a. The theory of money and credit. Indianapolis: Liberty Classics.

Mises, Ludwig von. 1980b. Planning for freedom. South Holland, IL: Libertarian Press.

Mises, Ludwig von. 1981. A new treatise on economics. In New individualist review. Indianapolis: Liberty Fund, pp. 323-6.

Mises, Ludwig von. 1985. Theory and history. Washington, DC: Ludwig von Mises Institute.

Mises, Richard von. 1957. Probability, statistics, and truth. New York: Macmillan.

$\rightarrow$ Morgenstern, Oskar. 1941. Professor Hicks on value and capital. Journal of Political Economy 49:361-93.

Mueller, Dennis, ed. 1997. Perspectives on public choice. Cambridge, UK: Cambridge University Press.

Nicholson, Walter. 1989. Microeconomic theory: Basic principles and extensions. New York: Dryden Press.

Nozick, Robert. 1997. On Austrian methodology. In Socratic puzzles. Cambridge, MA: Harvard University Press, pp. $110-41$.

O'Driscoll, Gerald, and Rizzo, Mario. 1996. The economics of time and ignorance. New York: Routledge.

Olson, Mancur. 1971. The logic of collective action: Public goods and the theory of groups. Cambridge, MA: Harvard University Press.

Posner, Richard. 1998. The economic analysis of law. New York: Aspen Publishers.

Prychitko, David. 1993. Formalism in Austrian-school welfare economics: Another pretense of knowledge? Critical Review 7:567-92.

Rizzo, Mario. 1979. Uncertainty, subjectivity, and the economic analysis of law. In Time, uncertainty, and disequilibrium, edited by M. Rizzo. Toronto: Lexington Books, pp. 71-89.

Rosen, Sherwin. 1997. Austrian and neoclassical economics: Any gains from trade? Journal of Economic Perspectives 11:139-52.

Rothbard, Murray. 1956. Towards a reconstruction of welfare and utility economics. In On freedom and free enterprise: Essays in honor of Ludwig von Mises, edited by M. Sennholz. Princeton, NJ: D. Van Nostrand, pp. 224-62.

Rothbard, Murray. 1962. Man, economy, and state. Los Angeles: Nash Publishing.

Rothbard, Murray. 1974. Ludwig von Mises and the paradigm for our age. In Egalitarianism as a revolt against nature and other essays. Washington, DC: Libertarian Review Press, pp. 134-46.

Rothbard, Murray. 1977. Power and market. Kansas City: Sheed Andrews and McMeel.

Rothbard, Murray. 1979. Comment: The myth of efficiency. In Time, uncertainty, and disequilibrium, edited by $\mathbf{M}$. Rizzo. Toronto: Lexington Books, pp. 90-95.

Rothbard, Murray. 1980. The essential von Mises. In Planning for freedom. South Holland: Libertarian Press, pp. 234-70.

Rothbard, Murray. 1988. Ludwig von Mises: Scholar, creator, hero. Washington, DC: Ludwig von Mises Institute.

Rothbard, Murray. 1997a. Praxeology, value judgments, and public policy. In The logic of action, Volume 1. Lyme, NH: Edward Elgar, pp. 78-99.

Rothbard, Murray. 1997b. Value implications of economic theory. In The logic of action, Volume 1. Lyme, NH: Edward Elgar, pp. 255-65.

Salerno, Joseph. 1993. Mises and Hayek dehomogenized. Review of Austrian Economics 6:113-46.

Thomsen, Esteban. 1992. Prices and knowledge: A market process perspective. New York: Routledge.

Varian, Hal. 1992. Microeconomic analysis. New York: W. W. Norton and Co.

Vaughn, Karen. 1994. Austrian economics in America. Cambridge, UK: Cambridge University Press.

Weatherford, Roy. 1982. Philosophical foundations of probability theory. Boston: Routledge and Kegan Paul.

$\rightarrow$ Yeager, Leland. 1997. Austrian economics, neoclassicism, and the market test. Journal of Economic Perspectives 11: 153-65. 